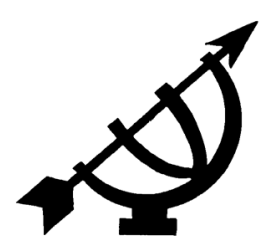

\title{
Paradigms, beliefs and values in scholarship: a conversation between two educationists
}

\author{
C.D. Roux \& J.L. van der Walt \\ Faculty of Education Sciences \\ Potchefstroom Campus \\ North-West University \\ POTCHEFSTROOM \\ E-mail: cornelia.roux@nwu.ac.za \\ hannesv290@gmail.com
}

\begin{abstract}
Paradigms, beliefs and values in scholarship: a conversation between two educationists

Scientific paradigms constantly play a role in scholarship, but researchers tend not to examine the roles of the belief and value systems associated with them. From time to time, however, a researcher may be confronted with a situation where such an analysis is unavoidable. This article takes the shape of a conversation between two researchers who have been working for several years in quite different research paradigms in the field of Religion Studies/Religion Education/Religion in Education. 1 They investigate the possibility of collaboration as they were initially trained at the same university. After their graduate studies, their ways parted, and they developed quite different
\end{abstract}

1 The terms Religion Studies/Religious Education/Religion in Education are defined in the South African Policy on Religion in Education (2003) and explicated in more detail in the Curriculum for Religious Studies for the FET-Band. The ambivalent use of the name for the subject Religious Education and/or Bible Education prior to 2003 led to confusion, and the various interpretations (nationally and internationally) that were bandied about necessitated the formulation of a definition for circumscribing the new subject in the curriculum, namely as a subject that would be fully inclusive. Its curriculum embraces a study of various different religions and value orientations (worldviews) and hence differs considerably from the content and definition of the previous religious education (cf. Summers \& Waddington, 1996; Krüger, 2003; Prinsloo, 2008). 
scholarly paradigms as well as belief and value systems. Their conversation not only highlights the differences in their respective current worldviews, belief systems, value systems, and academic approaches to Religious Studies, but also shows in practical terms how different scholarly paradigms (with their concomitant belief and value systems) can impact on researchers' (views of) scholarship, science practice and research in Religion Education and Religion in Education.

\section{Opsomming}

\section{Paradigmas, vooronderstellings en waardeoriënterings in wetenskapsbeoefening: 'n gesprek tussen twee opvoedkundiges}

Wetenskapsparadigmas speel deurlopend 'n rol in akademieskap, maar min navorsers verwoord eksplisiet hulle navorsingsparadigmas. 'n Navorser word soms wel gedwing om analities na sy/haar navorsingsparadigma te kyk. Hierdie artikel is in die vorm van 'n gesprek tussen twee navorsers wat vanuit hulle verskillende paradigmas op die terrein van die Religiestudies/ Religieuse Onderrig/Religie in Onderwys ${ }^{2}$ werk en moontlike samewerking vanuit hierdie verskillende paradigmas oorweeg. Hierdie oorweging spruit daaruit dat hulle aanvanklik aan dieselfde universiteit studeer het. Hulle weë het egter na hulle voorgraadse studiejare uiteen gegaan, en gaandeweg het hulle heeltemal verskillende wetenskaplike, paradigmatiese waardeoriënterings ontwikkel. Hulle gesprek lig nie slegs die verskille in hulle onderskeie lewensbeskouings, waardeoriënterings en benaderings tot Religiestudie uit nie, maar dui ook prakties aan hoe die verskillende wetenskaplike paradigmas (met hulle samehangende waardeoriënterings) 'n navorser se (sienings oor) akademieskap en navorsing in Religie in Onderwys en Religieuse Onderrig kan beïnvloed.

2 Die terme Religiestudies/Religieuse Onderrig/Religie in Onderwys word in die Suid-Afrikaanse Beleid oor Religie in Onderwys (2003) gedefinieer en in die kurrikulum vir Religiestudies in the VOO-band verduidelik. Die ambivalente gebruik van die naam van die vak, Religieuse Onderrig en/of Bybelonderrig, voor 2003 het tot verwarring gelei en verskillende interpretasies (nasionaal en internasionaal) het 'n definisie genoodsaak om die nuwe "vak" in die kurrikulum mee te identifiseer, naamlik as 'n vak wat inklusief van aard sou wees. Die kurrikulum daarvan sluit die bestudering van verskillende godsdienste en waardeoriënterings (werklikheidsbeskouings) in en verskil derhalwe aansienlik van die inhoud en definisie van die vorige religieuse onderrig/godsdiensonderrig (vgl. Summers \& Waddington, 1996; Krüger, 2003; Prinsloo, 2008). 


\section{Background}

Scientific paradigms constantly play a role in scholarship, but researchers tend not to examine the roles of the belief and value systems associated with them. From time to time, however, a researcher may be confronted with a situation where such an analysis is unavoidable. During our preliminary discussions about possible research collaboration we noted that although we started out from a similar worldview and scholarly paradigm, we began following different approaches to scholarship in general, and to science and methodology in particular. Both of us grew up in families as Christians in the protestant tradition (different denominations), and received our undergraduate training at a university that defined itself at that time as an institution for "Christian Higher Education" (a status that it surrendered in 2000 as part of merging with other higher education institutions). One of us (henceforth referred to as JV) continued developing his scholarship at that university in the context of what has become known as "Christian scholarship" in South Africa, the Netherlands, North America, Australasia and other parts of the world. His conversation partner (henceforth referred to as CR), completed her postgraduate studies at universities in South Africa as well as in Europe, that in principle have been following a more liberal approach that allows for a variety of scholarly paradigms in research.

Both of us became professors of Education and Religion in Education, and due to a wide range of academic activities received exposure to a variety of scholarly influences. Each published extensively in South Africa and abroad in collaboration with colleagues from a variety of backgrounds and with widely different belief and value systems. Because of our shared interest and expertise in the field of Education, particularly Religion in Education, and of having successfully completed several empirical research projects, we recognised the potential for research collaboration. In what follows hereafter, we explore differences that we noticed in terms of our respective scholarly paradigmatic approaches and their associated belief and value systems. The conversation contributes to the current knowledge construct of research in Religion in Education and its consequences for teacher education.

\section{The conversation}

\section{JV}

We both studied as undergraduates at the same university, at that time known as a University for Christian Higher Education. Whereas 
I continued my career as an academic at that institution, you continued your studies at another university and made similar progress there. How would you describe the scholarly training that you received there?

\section{CR}

The university where I continued my studies allowed its staff and students freedom of expression academically and to develop their scholarship in the context of a variety of research paradigms. For a long time, at least for most of the twentieth century, researchers in education worked in the context of phenomenology and positivism. In the last two decades there has been a shift towards (among others) social constructivism, critical (social) theory, personalism, the ecosystemic paradigm and postpositivism. I received exposure to all of these scholarly paradigms, but in the end formulated my own research paradigm to social science and scholarship. One of the reasons was my scholarly research interests in Religion in Education and teaching diverse worldviews.

How would you describe the postgraduate training that you received after your graduate studies?

\section{JV}

As you know, until 2000, the university where we received our undergraduate training used to characterise itself as an institution for Christian higher education. In line with the value system associated with that institutional character, it not only trained its students in the precepts of Christian scholarship, but also encouraged them to do research from the vantage point of the reformational worldview. Taking account of biblical principles, beliefs, values and reformational theological tenets in research was not only acceptable but also expected. The same applied for taking account of the imperatives flowing from the/a reformational life and worldview. However, researchers did not remain unexposed or impervious to the scholarly paradigms and methodologies that you mention. The professors made a point of highlighting particularly their shortcomings in terms of a reformational approach to science and research. Their critiques understandably flowed from convictions embedded in their Christian belief and value system. They nevertheless found some methods and approaches, such as hermeneutic interpretivism and critical reflection, reconcilable with their Christian scholarly approach. Others such as positivism, pragmatism and New Marxism/Leftism were, 
however, deemed unacceptable because of their alleged valueneutrality.

With the advantage of hindsight, I can today say that despite the much vaunted Christian character of the University before 2000, empiricism, pragmatism and positivism reigned supreme. Since 2000 , the institutional worldview of the university has been much the same as that of the university where you continued your studies. This meant that after 2000, I also had to find a paradigmatic niche for myself to work in. That, on the one hand, was characterised by remaining true to the basic tenets of Christian scholarship; but on the other hand, was "new" in that, for instance, I had to accommodate methods associated with a shift to post-positivism.

\section{CR}

This may well be the first time in my career that I feel myself compelled to deconstruct the meaning of being a scholar (educationist), particularly in the field of Religion in Education. Let me begin by saying that my ideas find their origin in the fact that I see myself as an individual with a personal narrative, liberated from preconceived ideas and intolerant religious perceptions. Although we started out with the same training, our interpretations of "reformed Christianity" differ not only because of our subsequent exposure to different academic influences, but also because of personal perceptions already shaped in our parental homes. These perceptions contribute to our respective religious understandings and literacy. My further involvement in Biblical Studies liberated me from seeing myself as a reformed Christian only. In time, I even distanced myself from the Christian worldview as a cultural whole that also embraces language, tradition, et cetera and which, in my opinion, was at the root of the Christian Nationalism that characterised apartheid (Roux, 1999a; 2007c). Put differently, already the grand narrative of my interdenominational upbringing as a child influenced my views of the truth. My search for the truth impacted on my worldview and hence on my research. My encounters with Rudolph Bultmann's Existence and faith (1961) and Joachim Jeremias's New Testament theology (1971) reinforced this liberation process in that they provided me with insights that differed from those that I encountered during my undergraduate studies.

\section{JV}

You say that your multidenominational upbringing, as well as your postgraduate encounters with the works of Bultmann and Jeremias, 
liberated you from the rather strict reformational perspectives that you encountered during your undergraduate studies?

\section{CR}

Yes. My grand narrative has its roots in the different Christian denominations that were part of my family's social composition. Already back then, I spontaneously reflected on the diversity in my family's intra-religious affiliations. All the differences and influences in my family connected family events in such a way that I began understanding each event as significant in religious and social terms, as part of a diverse totality. I learned to conduct my narrative about diversity as a social construct (cf. Elliot, 2006; Hinchman \& Hinchman, 1997), with the notion that diversity is an ever-changing process of prioritising and understanding the social world. There is a connection between my experiences in real life and the processes that I developed for research and scholarship.

One needs to understand one's own religious and social frame of reference together with its beliefs and values, including its historical and cultural context. The combination of my experience of diversity in my family life together with my historical and cultural context, not only influenced my worldview, but also the way in which I (re-) construct the social world (Grundy, 1987). My self-reflexivity is furthermore based on the theoretical underpinnings of a feminist paradigm (cf. Gatenby \& Humphries, 2000). I further explain this as a "feminist research paradigm (combined) with narration and reflexivity that engages a self-critical sympathetic introspection and auto-ethnography" (Roux, 2007a:508). My later involvement in national and international research projects in education, and specifically in multireligious and multicultural education, reinforced this tendency. The process of learning about myself and identifying stereotypes about my own and other's religious and cultural experiences helped me gain insight into others' religious and cultural ways of life as well as into their belief and value systems (Roux, 2007b; 2010a).

\section{JV}

Are you saying that although you grew up in a Christian parental home context - your upbringing in a diverse, i.e. multidenominational family and your later experiences both as postgraduate student and as researcher - helped widen your perspective to beyond a conservative reformational Christian viewpoint? 


\section{CR}

Yes, the process that I just described liberated me from a conservative (reformational) Christian orientation. I realised that I was able to link religious coherence, as well as being an insider/outsider (cf. McCutheon, 1999), in different denominations with my daily dealings with people, my environment, studies and existence. I learned to make sense of life experiences (cf. Chase, 2003) and to turn those experiences into hermeneutical tools for the promotion of academic competency. It became the basis of my scholarship and shaped the research paradigms that I chose for investigating Religion in Education (RiE).

\section{JV}

Please expand on your last remark. Knowing about your research paradigm(s) is important for any future research collaboration between us.

\section{CR}

My specialisation in Biblical hermeneutics in 1988 contributed to my search for the truth, as mentioned (cf. Knitter, 1985; 1994). Hermeneutics is key to deconstructing texts, contexts, contents, historical processes and facts in religion. I also learned to deconstruct the texts and contexts of our society (cf. Gadamer, 1975), applicable for education and to socially reconstruct a multireligious society. Deconstruction and social constructivism (Kuhn, 2003) are methods for searching for meaning in both theory and praxis in Religion in Education (Jackson, 1999; Roux, 2008; 2010a; Roux \& Du Preez, 2006; Slattery, 2009). The personal narrative that I have been describing so far, my personality, as well as my enquiring mind constantly urge me to deconstruct my understanding of the other (Roux, 2010a; 2010b) in all its different contexts: religious, social, political, economical and so on (Roux, 2007b; Kapuściński, 2008).

\section{JV}

Though I kept working in the so-called reformational Christian paradigm, I constantly took pains to embrace as many other research methodologies as possible that I found compatible with this paradigm or scholarly frame of thought. Some of the most important methods nowadays employed by Christian educationists are interpretivism (Feinberg \& Soltis, 1985:75-90; cf. McKay \& Romm, 1992: 48 ff.) combined with heuristics and hermeneutics (Danner, 1997; 
Higgs \& Smith, 2002:20 ff.; St Clair, 2005), social constructivism (De Muynck \& Van der Walt, 2006; cf. also Watzlawick, 2003; Dennett, 2003:47; Van Crombrugge, 2006:125 ff.) and critical theory, especially in its post-struggle form (Jansen, 2009:255 ff.; Schatzki, 2009:32 ff.; cf. also McKay \& Romm, 1992:100-109; Nel, 1995:123 ff.; Higgs \& Smith, 2002:79 ff.; Nieuwenhuis, 2010:9).

Despite this embracement of later developed methods and methodologies, I did not experience a break between my upbringing in my family environment, my university career, and research the way you seem to have. I find this break between your personal worldview and your scientific worldview intriguing. You are a person with a Christian worldview, and yet you seem to assume a secular (i.e. a supposedly non-religious) scientific worldview mode when doing research. Is this conclusion correct, namely that you tend to live in two separate worlds, as a person (spiritually, privately) and as a scholar (in the research environment, publicly) (cf. Davies, 1993:14)?

\section{CR}

No, I do not think so. In my opinion, my approach to research should not be construed as dualistic. I shared my personal narrative with you from the "l"-position or life stance. I presented the narrative in the first person singular because a narrative is a "window on inner life rather than on social worlds" (Gubrium \& Holstein, 2009:7). I took this stance for purposes of deconstructing the ontological self, mine included. You seem to want me to take a life stance also as the foundation for my scholarly work (research). I approach the matter differently: hermeneutics defines my philosophy and the way in which I deconstruct the social and scholarly world of education research (Roux, 2010b), as well as the environment of the narrative itself (Gubrium \& Holstein, 2009:127).

\section{JV}

I remain concerned about the break or schism between your personal and private life as a Christian and your public life as a researcher. You seem to work in and with two different belief and value systems, depending on what you are involved in, something personal and private or science as something public or secular. In your reply, you did not refer to the fact that you distinguish between your personal life as a Christian and your public life as a researcher. How does hermeneutics bridge this gap? 


\section{CR}

I want to draw upon an argument of Habermas (1988) as outlined in Adams (2006:63): "how one orientates oneself to a tradition once one becomes conscious of the vulnerability of its binding character". It is my consistent questioning and reflection on tradition that leads to a more enquiring stance, especially regarding research on Religion in Education and its diverse composition in South Africa and abroad. According to Habermas (Adams, 2006:64), only if one was "educated in a tradition one can question it from within". This leads to the questioning of the "authority of the tradition" and leads to more insights and rational decisions (Adams, 2006:64).

I draw further upon the notion that "hermeneutics is not merely the method of interpretation and understanding, but also an attempt to describe and explain the circumstances within which understanding must be able to take place" (Roux, 2007a:471; 2010a). I furthermore contend that religious literacy enables one to develop a religious conscience, which is not a humanistic faith but spiritual and humane in that it enables one to understand and be part of discourses about religious and social environments (Roux, 2010a). As far as the gap that you refer to is concerned, one could apply hermeneutics to the principles of Christianity as well. I can also argue, for instance, from a humanist position, that one recognises the humaneness of the historical Jesus. This should be the foundation of the religious literacy of every Christian, irrespective of denomination and a scholarly or scientific stance adopted as a researcher. The religious roots of humanism can be similarly analysed and explained (Lamont, 1997: 53-65). According to Lamont (1997:53) religions made a "substantial contribution to the ethical side of the Humanist tradition" in that "regardless of the theology that they formally profess, [their aim is] the alleviation of human suffering and the extension of human happiness upon this earth" (Lamont, 1997:63).

\section{JV}

You use hermeneutics and religious literacy for understanding and bridging gaps between various religious and worldview stances. However, my understanding of your approach is that, apart from and in supposed isolation of your Christian worldview belief and value system, you have assumed a (scholarly) hermeneutical position, and it is from this vantage point you contrive to bridge from (the heights of) scholarship the gaps between the different religious positions, including humanism. Put differently, by gaining a deeper understanding of each, you somehow connect them with one another. 
This makes sense to me as a scholarly method for understanding religious diversity and social interaction, but $I$ fail to see how it bridges the life conceptual gap inside you yourself as a person between your own private worldview, belief and value system, and your public life as a researcher applying the hermeneutical method (Van der Walt, 2007:230). You, therefore, seem to be living in two worlds: a private world replete with Christian principles, beliefs and value system, and a public world, where a scientific belief and value system (hermeneutics and religious literacy) reign supreme (and where your personal principles, beliefs and values supposedly have no say). Is this not a kind of intellectual schizophrenia (cf. Van den Beukel, 1996:11)? Is a person's worldview with its belief and value system not a unity (Van der Walt, 2008:86; 1994:54; also Jones, 1972:83; Craffert, 1997:193-194; Van Brummelen, 1994:24)? What is more, how sure can you be that your personal religious convictions, beliefs and values will not inadvertently affect the hermeneutics that you apply in understanding and deconstructing social reality?

\section{CR}

It is interesting to note how you define my private religious life and belief system. Nowhere did you mention the complexities of religious spiritualities (Roux, 2006). My worldview and beliefs may be humanistic and I may be a humanist in research contexts, as you say, but I am only being honest and truthful to my research terrain. I have combined the influences from my upbringing with my later development as a scholar. The way that I was brought up is part of my understanding and development of my worldview. I also have to be honest to the social science that I serve. I am convinced that a hermeneutic stance combined with social constructivism enables one to responsibly engage in education research, particularly in the field of Religion in Education and diversity.

\section{JV}

The purpose of this conversation is to see where we stand as far as our respective personal and scientific worldviews are concerned. Insight into each other's worldview convictions, belief and value systems will enable us to collaborate with the necessary respect for each other's views. My understanding of our exchange of thoughts and ideas so far is that I prefer to work from a consolidated (in this case, reformational) worldview, and you have developed a method of commuting between your personal and your scholarly worldview. I can see why you resorted to that approach: you expect it to enable 
you to operate without the supposed encumbrance of your personal and private religious and worldview convictions, beliefs and values when doing research or writing articles for scholarly journals. I, on the other hand, have through the years had to contend with the problem of reviewers and journals that were uncomfortable about the inclusion of Christian precepts in scholarly work. This has been changing of late; editors and reviewers seem to have become more tolerant of researchers explaining exactly where they come from in terms of their personal worldview, beliefs and values.

\section{CR}

A theoretical/scientific position such as the one that you prefer, leads to doing research based on a specific and subjective worldview, religious ideology, belief and value system - which in my opinion leads to "opaqueness". I approach this dilemma from another perspective, namely by asking: Who is the ontological self that does this research? Is she/he in service of human and social (education) science and research, or does his/her religious stance, religious doctrines, ideological position, belief and value system determine the course of the research? I would contend that a person's religious belief system is primarily in service of one's (personal) spiritual well-being but should never dictate the outcomes of scholarly work. One can argue that this is not possible - however, this research terrain requires reflexivity in order to understand its complexity. I tend to look beyond the data to the truthfulness presented by the participant.

\section{JV}

I agree with much of what you're saying, but would insist that one's worldview plays a role in whatever one does, wittingly or unwittingly. One's personal worldview should of course not dictate the outcomes of one's research, but one should be open and honest about where one is coming from in terms of personal worldview, religious convictions, belief and value system. I concur with Botha's (1990:17-18) statement a few decades ago that if one preferred not to work from the vantage point of your natural personal worldview when doing science, one tends to sprout a second ersatz (substitute) scientific worldview to work from. Or as Gray (2002:19-22) more recently argues, one works with science itself as that ersatz worldview. Alexander (2006:214) is correct in saying that knowledge "is always the possession of an embodied agent"; all researchers operate with "a view from somewhere". All forms of scholarship inadvertently receive pre-scientific nourishment from their religious and worldview 
roots, whether this is acknowledged or not. One cannot suppress one's worldview (and, for that matter, religious convictions, assumptions, beliefs and values) when doing research. One has to keep in mind the potential role that such pre-scientific/pre-theoretical convictions, assumptions, beliefs and values play in research and in determining the outcomes. We need to be honest in this respect, otherwise these subliminal convictions, et cetera may play an unwanted, unwarranted and/or unpredictable role in our scholarly work.

\section{CR}

My solution to the problem you are pointing out is to deliberately create an openness and sincerity about the problem under investigation, for instance, diversity among students or participants and the way they cope with and embrace religious and cultural diversity in their studies and research projects (Roux, 2009b:112). One must be honest about the empirical data and aware of one's insider/outsider position as researcher in multireligious and multicultural education research (McCutcheon, 1999; Roux, 2004). Understanding is an interpretive hermeneutical process that, I concede, may be influenced by one's preconceptions and prejudices. To circumvent this influence, one has to master the art of understanding: understanding the otherness (alterity) that appeals to us as scholars (Roux, 2010a).

As far as honesty is concerned: I concentrated on human activity of curriculum development in one of my public addresses on Curriculum development and transformation. I openly declared myself to be a disciple of Paulo Freire for his discourses on education (Freire, 1994; 2000) and regarding his understanding of transformative curriculum development as well as his claim that humans "are transformative beings and not beings for accommodation" (Freire, 2000: 36). One of the responses to my paper was not about the substance of my lecture but about discipleship being a Christian concept. I rejected this on the grounds that this was a narrow and simplified argument.

\section{JV}

The response that you received to your use of the word disciple resonates with one of my remarks above where I said that even in the current post-positivistic times, some scholars still remain suspicious of anything that even sounds vaguely religious. You used the term discipleship in the secular (i.e. supposedly non-religious) sphere of science that you demarcated for yourself as a result of the 
dualism that I referred to earlier, and yet you were accused of using a Christian concept in that domain.

I also make use of the hermeneutic-interpretive heuristic (in combination with other methods and approaches, as mentioned) in research, but I do so in full recognition of the backdrop of personal worldview convictions, beliefs and values that I openly declare. We might have discovered common ground for research collaboration in the use of this method, but there is a difference in application and, of course, of convictions and presuppositions at the pre-theoretical level.

\section{CR}

Yes, that may well be the case. Instead of working from my earliest Christian worldview as I understand you to have done throughout your career, I have been using a critical hermeneutical paradigm and reflexive stance (Roux, 2007b). I developed through my own theology, spirituality, ontology, reflexivity and identity - as part of my social construct - a hermeneutical and critical understanding of my ontological self. This influences the way that I deal with the alterity embedded in the other. Experiences in my research domain and in my scholarly endeavours constantly force me to interpret and reflect on my ontological self. Students and collaborators in research projects form part of my ontological self, as epistemologies of their own interpretations of integrated paradigms move towards a position where we reflect on two issues: our emotions and ontological selves (Roux, 2009b). In doing so, I understand my own development and identity. One could describe this identity or ontological self as multiple and professional identities developed during my journeys and based on grand narratives of family, friends, students, colleagues and especially co-researchers (Roux, 2007b). This view resonates with the notion of Slattery (2009:141) that a "post-modern community of interpreters and teachers will enter [a] hermeneutic circle and engage each other in the process of understanding the text, the lived experiences and the self in relation to the Other". As a researcher, I am constantly involved in dealing interactively with content, text, context and data, reflected and interpreted from my own as well as others' perceptions and interpretations.

\section{JV}

I agree with the hermeneutic process that you have been describing as part of understanding yourself, others (including your research co-workers), content, context, and so on. In a sense, you described 
the personal scholarly paradigm in which you do your research, including the presuppositions concomitant with it. I would submit, however, that one enters this hermeneutic circle as a person with a view from somewhere, as I have argued, and not as a neutral participant, unencumbered by a personal worldview. Part of this understanding (hermeneutic) process is also the gaining of insight into where the self and the other person come from in terms of their personal worldviews, belief and value systems.

\section{CR}

Critical reflections and interpretations cannot be based on, for instance, narrow biblical principles. The science of Hermeneutics intentionally changed the art of understanding (Gadamer, 1975), even of biblical texts. We have to widen our perspective. We are being influenced by diversity (socially, theologically and hermeneutically) in understanding the other, be it culturally or religiously. One also has to take note of an ever-changing social construct in societies and education. I concur with Knitter (2002:5) when he says that "religious life of mankind from now on, if to be lived at all, will be lived in a context of religious pluralism".

\section{JV}

I agree about the unacceptability of interpreting reality, of whatever nature, from a narrow (foundationalist) biblical perspective only. This is why I remarked at the outset that I have always tried to expand my scholarly perspective by employing the heuristic of hermeneuticinterpretivism and social constructivism (cf. Onwuegbuzie et al., 2009). Application of these methods also requires keeping in mind the personal worldviews and belief systems of all involved in the hermeneutic process, as well as taking cognisance of the increasing socio-conventional pluralisms characterising our environment.

In one of your previous responses you mentioned the matter of religious literacy. Do you also see religious literacy as something that can be acquired without the input of personal worldview convictions, beliefs and values?

\section{CR}

Let me begin by defining religious literacy. It is the ability to develop self-identity (the religious self) and to communicate with the other (other religions, belief systems and worldviews) (cf. Roux, 2010a; Levinas, 2006). Religious literacy requires processes of religious 
conscience in order to participate in discourses of diverse religious and social environments. The work of Knitter (1985) inspired me to confront my own stance and openness towards the other. It made me question my own religious literacy in terms of my own as well as that of the other. My personal religious, spiritual and cultural life never came under threat, because my experiences, as a sense of reality, contributed towards the real meaning and understanding of my religious self and hence to my religious literacy. The development of religious literacy, as part of the self-identity development process, involves a hermeneutical learning process in which one generates information that can be used to broaden one's research paradigm and scholarly approach. This action hermeneutics, where "hermeneutics does not necessarily always relate to the language that must be conveyed, but often to the interpretation of the action" (Roux, 2007b:471), involves dealing with imbedded knowledge and open dialogue with the other.

I think there is a lack of application of action hermeneutics in the current discourse about Religion in/and Education. As a result of the current dominance of so-called critical reflection and interpretivism (sometimes based on a biblical research paradigms only), there is little evidence of true critical reflection on reality and the social world that we are living in - the postmodern world of education research. The results of many research projects will support this conclusion (Roux, 2009a).

\section{JV}

Your description of how you acquired (and keep on acquiring) religious literacy tells me how you deal with your personal religiosity, worldview, belief and value system. I also find your Levinasian definition of religious literacy intriguing and worthy of further investigation. The same applies for your observation about the current lack of religious literacy in pedagogical circles. Although I agree that we have to instil religious literacy in our teachers and students, I am not quite convinced that we can broaden their outlook only in terms of religious literacy as you defined it.

\section{CR}

Research results in Religion in Education (cf., among others, Roux, 1996; 1997a; 1997b; 1998a; 1998b; 1999b; 2001; 2003; 2005; 2007c; 2008; Roux \& Du Preez, 2006; Roux \& Steenkamp, 1997; Ferguson \& Roux, 2003a; 2003b; 2004) indicate that many schools still promote (only) a mono-religious worldview, despite the multireli- 
gious composition of the school community. Many postgraduate studies under my supervision in different religious and cultural communities in South Africa and abroad, point out that this research is far more complex than there is room for discussion in this discourse. International research studies in this field are also not mentioned here (cf. literature on the REDCo-projects in EU countries, Scandinavia, England, and research in Australasia and the USA). I nevertheless maintain that teachers and students should broaden their outlook and for that reason, they have to become more religiously literate. This is especially important in teacher education.

One has to agree with Knitter (2002:10) that "the world religions are confronting each other as never before, and they are experiencing a new sense of identity and purpose, because they, like atoms and humans and cultures, are sensing the possibilities of a more pervasive unity through better relationships with each other". Therefore, as researchers we need to stretch our research paradigms and the way we perceive our own scholarly stances. As mentioned before, I would like to define my scholarship in relation to my understanding of hermeneutics as well as the social construction of the other. I set myself the task of mastering the art of inquiry and to continuously engage in cutting edge research. If this means stretching the boundaries of hermeneutics, critical (social) theory and social constructivism, I shall do so.

This conversation with you forced me to step back from my own scholarly work to look for what Boyer (1990) calls "connections, [that] build bridges between theory and practice, [and] communicate one's knowledge effectively". Among others, this means that one cannot engage in research without being honest about one's scholarly self. That is a notion that I am committed to.

\section{JV}

As we said right from the outset, this conversation was about understanding where each of us comes from in terms of the research and scholarly paradigms, worldview, belief and value systems. I initiated this conversation with the express purpose of understanding how you approach our field of investigation. I think that we have been honest in explaining the religious, worldview and value backgrounds that we have been working against so far; and as far as I am concerned, we can collaborate in research with a bit of give and take as far as methodology is concerned. We differ in terms of broad research orientation, but that does not preclude research cooperation. In saying this, I do not suggest that research 
methods are religiously or life-conceptually neutral. The application of the same or similar research methods will require ongoing discussions between us, mainly for the purpose of exposing the underlying paradigmatical, life conceptual and religious principles, presuppositions and assumptions that undergird our respective research methods.

I also take your point about being fully committed to your paradigmatic position. As I said, this conversation was not about convincing each other about the (in)appropriateness of stances, or belief and value systems, but rather to understand the deeper motives behind our research approaches. We have been doing what you have said we should do, namely reflect about our ontological selves.

\section{Concluding remarks}

Complete agreement about worldviews, life stances, viewpoints, belief and value systems need not be a conditio sine qua non for research collaboration. When we started this conversation, we knew that we would have to stand back from our scholarly work to reflect on and first describe our respective scholarly viewpoints, particularly the paradigmatic positioning of our approaches. We came to a conclusion that chimes with one recently drawn by Coletto (2008:464), namely that dialogue between "academic schools holding to different presuppositions" is rather difficult. In our case, the discourses differ and although dialogue was still possible, it was probably because of a partially shared religious, socio-conventional and scientific background. Although we share certain insights, there remain insurmountable differences which we shall have to respect. The differences do not preclude research collaboration between us, however the question about which paradigm will in the end prevail and be the more influential might crop up along the way. We work from different research paradigms in Religion in Education, and we are also aware that our research foci differ. CR is working mainly in multireligious and multicultural education environments with scholars from different religious and cultural backgrounds in South Africa, Africa and abroad. JV tends to work with scholars sharing his worldview and paradigmatic orientation. While this can be seen as an obstacle on the road to cooperation, it may also provide different perspectives on our research.

On the one hand, research, particularly in Religion in Education, should be wary of being unduly influenced by the tenets of research paradigms, worldviews/stances, belief and value systems. On the other hand, research is always to some extent affected by the re- 
searcher's belief and value system in terms of the methods chosen, and the research in- and outputs. This is a complex issue that even affects the type of pedagogy offered at teacher education institutions.

We end by inviting our readers to respond to the question:

To what extent, if at all, is it responsible and admissible to allow a particular belief and value system to influence pedagogy in an everchanging socially constructed multireligious and multicultural education environment?

\section{List of references}

ADAMS, N. 2006. Habermas and theology. New York: Cambridge University Press.

ALEXANDER, H.A. 2006. A view from somewhere: explaining the paradigms of educational research. Journal of philosophy of education, 40(2):205-221.

BOTHA, M.E. 1990. Metateoretiese perspektiewe op die sosiale wetenskappe/Metatheoretical perspectives on the social sciences. Potchefstroom: Central Publications.

BOYER, E. 1990. Scholarship reconsidered: priorities of the professoriate. New Jersey: The Carnegie Foundation for the Advancement of Teaching.

BULTMANN, R. 1961. Existence and faith: shorter writings of Rudolf Bultmann. Trans. \& ed. by S.M. Ogden. London: Meridian.

CHASE, S. 2003. Learning to listen: narrative principles in a qualitative research methods course. (In Josselson, R., Lieblich, A. \& McAdams, D.P., eds. Up close and personal: the teaching and learning of narrative research. Washington: American Psychological Association. p. 100-150.)

COLETTO, R. 2008. When "paradigms" differ: scientific communication between scepticism and hope in recent philosophy of science. Koers, 73(3):445-467.

CRAFFERT, P.F. 1997. The stuff worldviews are made of. Scriptura, international journal for Bible, religion and theology in South Africa, 61:193-212.

DANNER, H., ed. 1997. Hermeneutics and educational discourse. Johannesburg: Heinemann.

DAVIES, P. 1993. The mind of God. London: Penguin.

DE MUYNCK, B. \& VAN DER WALT, J.L., eds. 2006. The call to know the world. Amsterdam: Buijten \& Schipperheijn.

DENNET, D.C. 2003. Freedom evolves. New York: Viking Books.

ELLIOT, J. 2006. Using narrative in social research: qualitative and quantitative approaches. London: Sage.

FEINBERG, W. \& SOLTIS, J.F. 1985. School and society. New York: Teachers College Press.

FERGUSON, R. \& ROUX, C.D. 2003a. Teachers' participation in facilitating beliefs and values in Life Orientation programmes. South African journal for education, 23(4):273-275.

FERGUSON, R. \& ROUX, C.D. 2003b. Possibilities for mediation in the context of teaching and learning about religion. South African journal for education, 23(4):292-296. 
FERGUSON, R. \& ROUX, C.D. 2004. Teaching and learning about religions in schools: responses from a participation action research project. Journal for the study of religion, 17(2):5-23.

FREIRE, P. 1994. Pedagogy of the opressed. New York: Continuum.

FREIRE, P. 2000. Pedagogy of hope. New York: Continuum.

GADAMER, H-G. 1975. Truth and method. London: Sheed \& Ward.

GATENBY, B. \& HUMPHRIES, M. 2000. Feminist participatory action research: methodological and ethical issues. Women's Studies International Forum, 23(1):89-105.

GRAY, J. 2002. Straw dogs. London: Granta Books.

GRUNDY, S. 1987. Curriculum: product or praxis? Bristol: Falmer.

GUBRIUM, J.F. \& HOLSTEIN, J.A. 2009. Analysing narrative reality. London: Sage.

HABERMAS, J. 1988. On the logic of social science. Cambridge: Cambridge University Press.

HIGGS, P. \& SMITH, J. 2002. Rethinking truth. Landsdowne: Juta.

HINCHMAN, L.P. \& HINCHMAN, S.K. 1997. Memory, identity, community: the idea of narrative in human sciences. New York: State University of New York.

JACKSON, R. 1999. The inter-relatedness of subject, pedagogy and research approaches: theology, religious studies and religious education in England and Wales. (In Chidester, D., Stonier, J. \& Tobler, J., eds. Diversity as ethos: challenges for interreligious and intercultural education. Cape Town: Institute for Comparative Religion in Southern Africa. p. 84-101.)

JANSEN, J.D. 2009. Knowledge in the blood. Stanford: Stanford University Press.

JEREMIAS, J. 1971. New Testament theology. New York: State University of New York.

JONES, W.T. 1972. World views: their nature and their function. Current anthropology, 13(1):79-91.

KAPUŚCIŃSKI, R. 2008. The other. London: Verso.

KNITTER, P. 1985. No other name? A critical survey of Christianity. Maryknoll: Orbis Books.

KNITTER, P. 1995. One earth many religions: multifaith dialogue and global responsibility. Maryknoll: Orbis Books.

KNITTER, P. 2002. Introducing theologies of religions. Maryknoll: Orbis Books.

KRÜGER, J.S. 2003. The new policy on religion in education: theoretical points of departure and context. Religio: journal for religious studies, 1:4-10.

KUHN, T.S. 2003. On scientific paradigms in social construction: a reader. Ed. by M. Gergen \& K.J. Gergen. London: Sage.

LAMONT, C. 1997. The philosophy of humanism. New York: Humanist Press.

LEVINAS, E. 2006. Entre nous: thinking-of-the-other. Reprinted. Trans. by M.B. Smoth \& B. Harshav. London: Continuum.

MCCUTHEON, R.T. 1999. The insider/outsider problem in the study of religion. London: Cassell.

MCKAY, V. \& ROMM, N. 1992. People's education in theoretical perspective. Pinelands: Maskew Miller Longman.

NEL, B.F. 1995. Critical theory: origins, central concepts and education. (In Higgs, P. Metatheories in philosophy of education. Johannesburg: Heinemann. p. 123-138.) 
NIEUWENHUIS, J. 2010. Social justice in education revisited. Paper presented at the Oerebro-UNISA International Conference, 1-3 February.

ONWUEGBUZIE, A.J., JOHNSON, R.B. \& COLLINS K.M.T. 2009. Call for mixed analysis: a philosophical framework for combining qualitative and quantitative approaches. International journal of multiple research approaches, 3(2):114-139.

PRINSLOO, P. 2008. A critical evaluation of the South African Policy on Religion and Education (2003). Pretoria: University of South Africa. (Ph.D. thesis.)

ROUX, C.D. 1996. Paradigm shift - Christian student-teachers in a multireligious education programme. Religious education (South African edition), 54(2):7-10.

ROUX, C.D. 1997a. Biblical values and multireligious education in the primary school: problems and proposals. Scriptura international journal for Bible, religion and theology in Southern Africa, 60(1):63-70.

ROUX, C.D. 1997b. Redefining of the role of religious education teachers in a multicultural and multireligious school environment. HSRC-Research Report. (Workshop addendum.)

ROUX, C.D. 1998a. Paradigm shift in teaching religion. Journal for the study of religion, 11(2):125-138.

ROUX, C.D. 1998b. The need for a paradigm shift in teaching religion in multicultural schools in South Africa. South African journal of education, 18(2):84-89.

ROUX C.D. 1999a. Paradigm shift in teaching religion. (In Tayob, A. \& Weisse, W., eds. Religion and politics in South Africa - from apartheid to democracy. Münster: Waxmann. p. 99-109.)

ROUX, C.D. 1999b. Facilitating religion in life orientation programmes: challenges for a developing multicultural society. Journal for the study of religion, $12(1 \& 2): 113-122$.

ROUX, C.D. 2001. Religion in education in South Africa: myth or reality? Panorama international journal of comparative religious education and values, 13(1):17-26.

ROUX, C.D. 2003. Playing games with religion in education. South African journal of education, 23(2):130-134.

ROUX, C.D. 2004. Religion and peace: the role of religious education and values. Panorama, international journal of comparative religious education and values, 16:71-84.

ROUX, C.D. 2005. Religion in education: perceptions and practices. Scriptura, international journal for Bible, religion and theology in Southern Africa, 89:293-306.

ROUX, C.D. 2006. Children's spirituality in social context: a South African example. The international journal of children's spirituality, 11(1):151-163.

ROUX, C.D. 2007a. Collaboration in teacher education through research in multicultural education. South African journal for higher education, 21(3):503-519.

ROUX, C.D. 2007b. Hermeneutics and religion teaching and learning in context social constructivism. Scriptura, international journal for Bible, religion and theology in Southern Africa, 96(3):469-485.

ROUX, C.D. 2007c. Interreligious learning: teachers' abilities and didactic challenges. (In Pollefeyt, D., ed. Interreligious learning. Louvain: Peeter. p. 90-103.) (Bibliotheca Ephemeridum Theologicarum Lovaniensium.) 
ROUX, C.D. 2008. The development of a pedagogy in the context of diversity and inclusivity. (In Berger, M-J., ed. Issues of diversity, inclusion and beliefs. Ontario: University of Ontario, Faculty of Education. p. 37-50.)

ROUX, C.D. 2009a. Religion in education: who is responsible? Alternation, 3:330.

ROUX, C.D. 2009b. Religion education as praxis: voices and narratives on teaching and learning experiences. Alternation, 3:112-137.

ROUX, C.D. 2010a. Religious literacy and human rights literacy as prerequisite for human rights education. (In Durka, G., Gearon, L., De Souza, M. \& Engelbretson, K., eds. International handbook for interreligious education. Part 2. Dordrect: Springer. p. 991-1015.)

ROUX, C.D. 2010b. Education research versus educational research: a hermeneutical justification. Prestige lecture. Faculty of Education Sciences, North-West University (Potchefstroom Campus), South Africa, 15 March 2010.

ROUX, C.D. \& DU PREEZ, P. 2006. Clarifying students' perceptions of different belief systems and values: prerequisite for effective educational praxis. South African journal for higher education, 30(2): 514-531.

ROUX, C.D. \& STEENKAMP, D. 1997. The Christian teacher and multireligious education. Pretoria: Via Africa \& Nassau.

SCHATZKI, T.R. 2009. Dimensions of social theory. (In Jacklin, H. \& Vale, P. Re-imagining the social in South Africa: critique, theory and post apartheid society. Scottsville: KZN Press. p. 29-46.)

SLATTERY, P. 2009. Curriculum development in the post-modern era. London: Routledge.

ST CLAIR, R. 2005. Similarity and superunknowns: an essay on the challenges of educational research. Harvard educational review, 75(4):435-453.

SUMMERS, H.C. \& WADDINGTON, R.R. 1996. Religious education for transformation. Pretoria: Kagiso Trust.

VAN BRUMMELEN, H.W. 1994. Steppingstones to curriculum: a biblical path. Seattle: Alta Vista College Press.

VAN CROMBRUGGE, H. 2006. Denken over opvoeden/Thinking about education. Antwerp: Garant.

VAN DEN BEUKEL, A. 1996. Met andere ogen/With other eyes. Baarn: Ten Have.

VAN DER WALT, B.J. 2007. Transforming power. Potchefstroom: Institute for Contemporary Christianity in Africa.

VAN DER WALT, B.J. 2008. The eye is the lamp of the body: worldviews and their impact. Potchefstroom: Institute for Contemporary Christianity in Africa.

WATZLAWICK, P., ed. 2003. An introduction to radical constructivism: the invented reality. New York: Norton.

\section{Key concepts:}

beliefs

education

paradigms

scholarship

values 


\section{Kernbegrippe:}

akademieskap

opvoedkunde

paradigmas

waarde-oriënterings

waardes 